\title{
The Urgent Need for Anticolonial Media Literacy
}

\author{
Ashley Cordes \\ University of Utah \\ U.S. A. \\ Leilani Sabzalian \\ University of Oregon \\ U.S. A.
}

ABSTRACT: In this article, we advocate for anticolonial media literacy as an important complement to critical race media literacy. Given pervasive misrepresentation of Indigenous peoples in media, teachers must explicitly learn to challenge colonizing and dehumanizing representations of Indigenous life in the media and help their students to do the same. Drawing from several Native studies theories, we forward anticolonial media literacy as a tool to help teachers detect and interrupt colonial logics. After modeling anticolonial medial literacy in practice, we draw from Nambé Pueblo scholar Debbie Reese's framework of "critical Indigenous literacies" to support teachers in including and creating respectful alternatives.

KEYWORDS: media literacy, critical race theory, anticolonial, settler colonialism

\author{
The Need for Critical Race Media Literacy \\ Native Studies Theories \\ Modeling Anticolonial Literacy in Practice \\ Beyond Critique and Toward Critical Indigenous Literacies \\ References \\ Author Contact
}

When we initially started writing this article, we were fresh on the heels of the 54th annual Superbowl in which the Kansas City Chiefs, who draw heavily on arrowhead symbolism, "war chants," faux drums, and a broader history of Native degradation, played (and defeated) the San Francisco 49'ers. While it has become "socially unacceptable to express blatant antagonism toward people of color," Native peoples continue to "experience overt racism in the form of racial epithets like '[r* $\left.r^{*} s k^{*} n\right]$,' 'injun,' and '[squ ${ }^{*} w$ ]' and horribly distorted depictions of Natives as mascots, reminiscent of the propaganda used against black, Irish, and Jewish people in the nineteenth and twentieth centuries" (Robertson, 2015, pp. 113-114)1. Following the Superbowl, Indigenous peoples faced a double mode of oppression as they were chastised for their critiques of dehumanizing

1 We follow the lead of organizations like the National Congress of American Indians (NCAl) that use an asterisk when spelling out racist slurs used against Indigenous peoples (http://www.ncai.org/proudtobe). 
representations that accompanied this game. Native critiques of the racist photos, videos, and stories circulating in media (e.g., fans donning redface, adorning themselves in feather headdresses, or performing the tomahawk chop with one hand while holding a beer in another) resulted in further hostility towards Native peoples, accusations of "political correctness," and even escalated to death threats. The vitriol that circulated online on Superbowl Sunday likely followed students and teachers back to their classrooms the next morning.

Most recently, the Washington $\mathrm{R}^{*} \mathrm{dsk}^{*}$ ns announced their decision to change the team's name and logo (though they have yet to announce a replacement). A quick glance at social media following the announcement highlights similar hostility toward Native advocates and others supporting the decision. We write this article with the Native students in mind who navigated the hostility of their peers, perhaps even their teachers, the day following the Superbowl, and with deep appreciation for the Native advocates who worked tirelessly for decades advocating for Washington to change its name.2

The hypervisible display of settler superiority, racism, and Indigenous erasure at the Superbowl illustrates one of many ways Native peoples are dehumanized in media. The overt racism that Native peoples experience "is not confined to hate groups but is visible in everyday discourse and throughout the media" (Robertson, 2015, p. 114). Robertson refers to this dynamic as legitimized racism:

Racism against American Indians has been normalized and institutionally legitimized, thereby rendering it invisible. To legitimize is to make legitimate, that is, to justify, reason, or rationalize in accordance with established or accepted patterns and standards. In other words, the institutions that shape social normsthose seen as social authorities-reproduce symbolic racial violence against American Indians through legal structures, public education locations, consumer products, sports associations, and so on. (pp. 114-115)

Supporting students in detecting and disrupting the dehumanization of Indigenous peoples, requires first that teachers themselves can recognize the varied ways media legitimizes racism against Indigenous peoples (Robertson, 2015). Given that discourses and narratives circulating in media are often not only racist in nature but also colonial,

2 Indigenous activists and academics have long advocated for the Washington team to change its name. Susan Shown Harjo (Cheyenne/Hodulgee Muscogee) has led this fight in her landmark lawsuit, Harjo et al. v. Pro Football, Inc. filed in 1992. Co-plaintiffs included Ysleta del Sur Pueblo Governor Raymond D. Apodaca, Jr., Dr. Manley A. Begay, Jr. (Navajo), Vine Deloria, Jr. (1933-2005; Standing Rock Sioux), Norbert S. Hill, Jr. (Oneida), William A. Means (Oglala Lakota) and Mateo Romero (Cochiti Pueblo). Other important leaders include Amanda Blackhorse (Diné), Crysal Echohawk (Pawnee), Stephanie Fryberg (Tulalip), Richard Grounds (Yuchi/Seminole), Adrienne Keene (Cherokee), and Charlene Teters (Spokane), among others, as well as organizations like the National Congress of American Indians and IllumiNative. It is also important to note that despite decades of pressure from Indigenous advocates, the team likely changed its name in response to pressure from corporations like FedEx, Nike, and Pepsi (who themselves faced pressure from investors). The decision to finally change the name illustrates what critical race theorist Derrick Bell describes as "interest convergence," a theory that describes how social change often occurs, not because something is finally found moral or just, but because dominant interests align with advocacy (in this case, the interests of of the non-Native owners of the Washington franchise finally aligned with those of Native advocates). 
detecting and interrupting legitimized racism will require teachers to be equipped with both critical race media literacy (Yosso, 2002), as well as anticolonial media literacy.

Anticolonial media literacy builds upon the concept of anticolonial literacy (Sabzalian, 2019a). Akin to "equity literacy," which involves the ability to recognize, respond, and redress bias, discrimination, and inequity in education, as well as to cultivate and sustain bias-free educational spaces (Gorski \& Swalwell, 2015, p. 37), anticolonial literacy involves "the ability to critically read and counter Eurocentric and colonizing educational discourses and practices" (Sabzalian, 2019a, p. 202). Preparing teachers to be versed in anticolonial media literacy can support Native students specifically in developing a "critical race vocabulary" that affords them opportunities to "name their pain" (Matias \& Liou, 2015, p. 615). More broadly, anticolonial media literacy can support all students in recognizing and deconstructing dehumanizing colonial logics in media and generate anticolonial alternatives. We use the term anticolonial, following Patel (2016), to "draw into relief the ways in which settler coloniality must be known to be countered," a contrast and complement to the term decolonial which "should always address material changes" (p. 7). Anticolonial literacy is an important complement to decolonial praxis. In this article, we make a more explicit link to the need for media literacy, and its necessary corollary, critical race media literacy (Yosso, 2002).

Though we offered this Superbowl vignette as an example of the way society and media sanction ongoing dominant colonial narratives, examples of Indigenous erasure and dehumanization abound. For example, celebrities and ordinary individuals alike still wear headdresses (Cordes \& Merskin, 2019; White, 2017), and racist renderings of the large-nose caricatures of Chief Wahoo are plastered in high school gyms (Strong, 2004). Statues of pioneers, enslavers, and other monuments of white 3 supremacy still stand in cities, though there has been a notable increase in their necessary removal recently (Attiah, 2020). While it is important that educators can critically read and counter these explicitly degrading examples, educators must also learn to read and counter subtler colonial logics that surface in media.

Media is significant for its role in storing historical memory, reflecting/projecting identity politics, and producing and challenging hegemonic discourses. Media are texts that can be read through their codes and structures that work to produce cultural myths (Barthes, 1972). Educators must learn to read what is not explicit or learn to read the erasures in media. Anticolonial media literacy fosters teachers' ability to detect the way Indigenous peoples are absent from particular representations, and the larger political ramifications of these erasures. To be sure, representational literacy is more important than being able to point at media texts and discern them as "good" (politically correct/humanizing) representations or "bad" (politically incorrect/harmful) representations; it also involves recognizing the ways media texts are re-presentations of

3 Following Rosiek and Kinslow (2016), we write the term "white" in lowercase "because at this point in our history there is no collective 'White' identity organized around the project of resistance to institutionalized racism" and we capitalize the terms "Black" and "Indigenous" as they signify "conscious project[s] of resisting institutionalized racism," (p. xxxvii). Further, we do not wish to further embolden white supremacists who typically capitalize "White," and whose collective racial identity is organized specifically around promoting white supremacy. 
dominant cultural ideology and hegemony (Hall, 1997). Re-presentations help members of society make sense of who they are; thus, Indigenous scholars advocate for "the reestablishment of representational sovereignty" or the right for Indigenous peoples to have a say by producing and consuming texts that are not damaging to our communities (Lewis, 2006, p. 175). This concept has also been referred to as "rhetorical sovereignty" in the context of writing (Lyons, 2000), and "visual sovereignty" in the context of film (Raheja, 2010).

To set the context for anticolonial media literacy, we draw on existing literature that articulates the need for critical race media literacy. We complement this body of literature by turning to Tribal Critical Race Theory (hereafter TribalCrit) (Brayboy, 2005). As a means of fleshing out TribalCrit's central claim-that "colonization is endemic to society" (p. 429)-we turn to two Native studies theories to support teachers in recognizing the varied ways colonial logics surface in media: firsting, replacing, and lasting offered by Jean O'Brien (2010), and settler grammars conceptualized by Dolores Calderón (2014). We then put these concepts to work on specific media texts to model anticolonial media literacy in practice. Because anticolonial media literacy requires moving beyond critique to also seek out and offer students meaningful and respectful alternatives, we end by highlighting Debbie Reese's advocacy for "critical Indigenous literacies" (Reese, 2018).

\section{The Need for Critical Race Media Literacy}

Media literacy equips students with tools to analyze the power of media in society including media construction, production, consumption and its effects (Buckingham, 2013; Kellner \& Share, 2005). Beyond individualized skill sets, media literacy allows students to relate to others in their communities (Jenkins, Ito, \& boyd, 2016) and engage in contemplative practice to assess the power of media in helping achieve social transformation (Morell, 2012). In her foundational article, "Critical Race Media Literacy: Challenging Deficit Discourse about Chicanas/os," Tara J. Yosso (2002) draws on critical race theory (CRT) to infuse media literacy with the projects of racial and social justice. Yosso argues this conjoining, what she refers to as critical race media literacy (CRML), is necessary as schools and media both reproduce "delusional ideas" about racism, sexism, and classism (p. 53). Drawing on Freire's conception of literacy that advocates for providing "students with the tools to not only read the word but also to read the world," Yosso argues, "CRT can challenge students to critically 'read' the racism, sexism, and classism in entertainment media portrayals of Chicanas/os-to develop critical media literacy" (p. 54). Through a series of curriculum sessions, Yosso equipped students with social science theories, concepts, and language in media, as well as critical race vocabulary to support them in detecting the ways media reproduce stereotypes and deficit thinking about Chicanas/os. Yosso found critical race media curriculum sessions effective "in describing how media, through repetition of negative portrayals, teach Chicanas/os that they are inferior to whites, and in turn, whites learn that they are better than Chicanas/os" (p. 59). Students also linked these negative media portrayals to "material repercussions for Chicano communities, including fewer financial aid opportunities and community support programs" (p. 59). While CRML "cannot be a magic bullet," Yosso argued it can "facilitate students becoming critically conscious of themselves in relation to the structures of power and domination in their world" (p. 59). 
CRML has since been taken up by scholars in generative ways (Hawkman \& Shear, 2017; Hawkman \& Van Horn, 2019; King, 2017; Lozenski \& Chinang, 2019). King (2017), for example, builds on Yosso's work to illustrate how the Center for Media Literacy's (CML) "Key Questions for Media Inquiry," fail to "explore the dynamics of race or provide a racial lexicon" (p. 36). To remedy this, King revises CML's key question to foster racial literacy (i.e., supplementing the question "Who created this message?" with the question "What are the racially constructed messages conveyed through the news?" (p. 37). Hawkman and Shear (2017) also build on Yosso's framework to suggest that teachers guide students through a process of confrontation (confronting problematic racial representations in media), interrogation (questioning and critiquing those representations), and navigation (offering students opportunities to challenge those representations). (See also Hawkman \& Van Horn, 2019, pp. 107-108). Anticolonial media literacy is indebted to and builds on this important scholarship.

\section{Anticolonial Media Literacy as an Important Complement}

CRML is important for detecting the ways race is sutured to globalized media (Yosso, 2002); however, TribalCrit (Brayboy, 2005) offers an important complement to CRML. TribalCrit is based on nine tenets, which help outline contours of anticolonial media literacy:

1. Colonization is endemic to society.

2. US policies toward Indigenous peoples are rooted in imperialism, White supremacy, and a desire for material gain.

3. Indigenous peoples occupy a liminal space that accounts for both the political and racialized natures of our identities.

4. Indigenous peoples have a desire to obtain and forge tribal sovereignty, tribal autonomy, self-determination, and self-identification.

5. The concepts of culture, knowledge, and power take on new meaning when examined through an Indigenous lens.

6. Governmental policies and educational policies toward Indigenous peoples are intimately linked around the problematic goal of assimilation.

7. Tribal philosophies, beliefs, customs, traditions, and visions for the future are central to understanding the lived realities of Indigenous peoples, but they also illustrate the differences and adaptability among individuals and groups.

8. Stories are not separate from theory; they make up theory and are, therefore, real and legitimate sources of data and ways of being.

9. Theory and practice are connected in deep and explicit ways such that scholars must work towards social change. (pp. 429-430)

As the tenets of TribalCrit illustrate, colonialism includes other forms of oppression, such as racism, white supremacy, and capitalism. Tenet two, for example, underscores how imperialism afforded "the means through which concepts of what counts as human could be applied systematically as forms of classification, for example through hierarchies of 
race and typologies" (Smith, 2012, p. 26). TribalCrit activates the potential of CRML to specifically attend to the ways media representations can in turn reproduce racist imperatives of settler colonialism.

Settler colonialism is an ongoing structure predicated on the seizure of Indigenous homelands and the continual justification of entitlement to those lands, the erasure of Indigenous peoples (physically and ideologically), and the practice of chattel slavery to ensure profit from Indigenous lands (Tuck \& Yang, 2012; Wolfe, 2006). Settler colonialism forwards a useful (but problematic) triad-settler-native-slave-that broadens anlyses of white supremacy and antiblackness to also account for Indigenous erasure and dispossession (la paperson, 2017). Though often interpreted as describing racial identities, la paperson clarifies,

the triad is a figurative shorthand-settler-native-slave are figurae to describe relations of power with respect to land. They sound like identities, but they are not identities per se. As figurae, they represent sites of exception that reveal the underlying logic of settler colonial power. (p. 9)

The logic of settler colonial power, which is primarily concerned with the acquisition and maintenance of land, cannot be understood through racial analyses alone. For example, though whiteness was initially a legal requirement for US citizenship, shifting requirements enabled people of color to be included in the settler colonial project of nation-state expansion (and correspondingly, Indigenous dispossession).4 As another example, an Indigenous person can be white-coded, but a citizen of a tribal nation (which is a political, rather than racial, identity). Misrepresentations of Indigenous peoples that circulate in the media may be racist, but can also undermine Indigenous sovereignty. And the desire to claim Native ancestry, often via "a long-lost ancestor who is rumored to have had 'Indian blood," is not only a desire for a racial identity, but as Tuck and Yang (2012) describe, often reflects a yearning for innocence, a way for settlers "to mark themselves as blameless in the attempted eradications of Indigenous peoples" (p. 10). As such, analyses of settler colonialism offer teachers important context to bolster critical race media literacy. Anticolonial media literacy involves critically examining the ways media reproduces both racism and colonialism (the latter of which involves attending to issues of land, sovereignty, and Indigenous knowledge and kinship systems).

Reclaiming Native Truth (First Nations Development Institute \& Echo Hawk Consulting, 2018), a national survey that documented what Americans across the US "think (and don't know) about Native Americans and Native issues" (p. 4), found that media has played a key role in erasing and dehumanizing Indigenous life. Indigenous peoples face unique challenges, as they are often "romanticized" in the past and

\footnotetext{
${ }_{4}$ People of color can participate in the dispossession of Indigenous peoples, but it is important to clarify again that the triad does not describe racial identities; rather, it describes "technologies [that] operate everywhere on everybody in intersecting, sometimes contradictory ways, and always with a dynamic specificity that radically changes with context" (la paperson, 2017, p. 8). Instead of asking broadly if Black people are settlers (which is rooted in the faulty logic that "everyone non-Native is assumed to fit the category of settler: settlers $=$ non-Natives $=$ people of color $=$ migrants of color $=$ settlers of color $=$ Black people"), la paperson urges us to ask more specific questions, such as "when and where have Black communities [and other communities of color] been settlers? When and where do they cease to be settlers?" (pp. 7-8).
} 
"invisible" in the present (p. 4). Because many of the people surveyed admitted they lacked personal relationships with Native people, it is necessary to consider how media contributes to widespread public misperceptions about Indigenous peoples as "people fall back on media tropes of the savage/noble warrior or reports of negative outcomes such as poverty and alcoholism rather than seeing Indians in everyday roles" (p. 8).

Anticolonial media literacy involves critically interrogating these "media tropes" and situating them within a legacy of settler colonial erasure. Misrepresentation and commodification of Native Hawaiian culture, Kanaka Maoli scholar Lisa Kahaleole Hall (2005) argues, "undermine[s] sovereignty struggles in a very fundamental way" (p. 409). Hall continues,

A culture without dignity cannot be conceived of as having sovereign rights, and the repeated marketing of kitsch Hawaiian-ness leads to non-Hawaiians' misunderstanding and degradation of Hawaiian culture and history. Bombarded by such kitsch along with images of leisure and paradise, non-Hawaiians fail to take Hawaiian sovereignty seriously and Hawaiian activism remains invisible to the mainstream. (p. 409)

Hall's analysis, when broadened to include other Indigenous peoples, illustrates the link between media and settler colonialism. The need for anticolonial media literacy is particularly acute given the lack of Indigenous representations in media (Fryberg, Covarrubias, \& Burack, 2016). Scarce representations of Indigenous peoples in media give more weight to the images that are included (Fryberg, Markus, Oyserman, \& Stone, 2008). Students and teachers alike must learn to challenge these racist colonial tropes, the most common of which "include negative stereotypes (e.g., as poor and uneducated), caricatures and cartoons (e.g., racist sports team mascots, Disney's Pocahontas), and 18th and 19th-century historical figures (e.g., warrior chiefs, teepee-dwelling figures" (Fryberg, Covarrubias, \& Burack, 2016, p. 7). One First Nations Elder termed this pattern of media tropes the 4Ds: Native people are included when they are drumming, drinking, dancing, or dead (McCue, 2014). Colonial tropes within media shape (and often distort) the ways people interact with Indigenous peoples "(i.e., 'Really, you don't look like an Indian!')" (Fryberg, Covarrubias, \& Burack, 2016, p. 7). At a more fundamental level, colonial tropes in media "limit which future possible goals are seen as viable for Indigenous people," the "[p]ossible selves-cognitive expressions of people's enduring goals, aspirations, motives, and fears" that Indigenous youth might imagine for themselves (Fryberg, Covarrubias, \& Burack, 2016, p. 9).

Anticolonial media literacy reads against these narrow and dehumanizing framings of Indigenous life, framings often rooted in damage, and instead, seeks out representations rooted in desire (Tuck, 2009). Desire, Tuck argues, is an important "antidote" to damage-based narratives that position Native students as damaged/at-risk. Further, anticolonial media literacy recognizes that international literacy is as necessary as racial representational literacy, to account specifically for Native nationhood and sovereignty. 


\section{Native Studies Theories}

TribalCrit justifies and sets the context for anticolonial media literacy. Correspondingly, the field of Indigenous studies provides essential theories, concepts, and analyses that can foster and flesh out anticolonial media literacy in practice. Indigenous studies is an interdisciplinary field that is diverse, yet united by various shared themes and commitments. An exhaustive description of the field is beyond the scope of this article; however, some expressed commitments of the discipline include defending Indigenous homelands, sovereignty, and nationood (Cook-Lynn, 1997; Rowe \& Tuck, 2017), affirming the inherent value of Indigenous knowledges, languages, values, philosophies, and lifeways (Lomawaima, 2006), enhancing well-being of Indigenous peoples, communities, and nations (Lomawaima, 2006), and utilizing Indigenous analyses to critique dominant discourses, disciplines, and normalizing logics of settler society (Moreton-Robinson, 2015).

In this section, we introduce two Native studies theories that support anticolonial media literacy. In highlighting the value of these theories, we demonstrate the vast potential of Native studies to enrich Yosso's (2002) robust conception of critical race media literacy.

\section{Firsting, Replacing, and Lasting}

In her book Firsting and Lasting: Writing Indians Out of Existence in New England, White Earth historian Jean O'Brien (2010) describes ideological methods of conquest that she refers to as "firsting," "replacing," and "lasting." Firsting is "a straightforward scripting choice that subtly argues for the sole legitimacy of New English [or more broadly, settler] ways" (p. 6): local historical narratives that laud the first settler to arrive or be born in a town, or the first settler house or institution to be built, etc. Accompanying firsting is the discursive method of "replacing" Indigenous peoples. Whereas firsting is a method of claiming Indigenous lands, replacement narratives assert entitlement to those lands by supplanting Indigenous peoples and claiming indigeneity for themselves. Monuments, place-names, or commemorations, for example, often function to replace Indigenous presence and assert settler authority. "Lasting" is another method of erasure that justifies settler presence on Indigenous lands. O'Brien documents the ways local histories position Indigenous peoples as the "last" of their Tribe, irrespective of their continued presence.

Taken together, firsting, replacing, and lasting highlight a cartography of erasure and the rhetorical and discursive means through which settlers narrated (and continue to narrate) themselves as modern, and Indigenous peoples as primitive and a vanishing race. And whereas O'Brien's analysis focused on local histories in New England, these ideological methods of conquest are pervasive nationwide and in Indigenous contexts across the globe (Smith, 2012). Firsting is rehearsed each year as cities celebrate their birthdays. Similarly, lasting narratives pervade movies, such as The Last of the Mohicans (1992) or photographic projects like Edward Curtis' "The North American Indian" which was premised on the idea of "The Vanishing Race" (Curtis, 1907-1930). Each offers a generative means to facilitate students' anticolonial media literacy by helping them read the ways Indigenous peoples are often, drawing from the title of her book, "written out of existence." 


\section{Settler Grammars}

Another Native studies theory that can facilitate anticolonial media literacy is Mexican/Tigua scholar Dolores Calderón's (2014) concept of "settler grammars." Making explicit the ways social studies curriculum is rooted and invested in the settler colonial project, Calderón offers settler grammars as discursive means through which Indigenous peoples are erased, and settlement is rehearsed and maintained. "The heart of settler colonialism" Calderón writes, "has to do with legitimating settler territorial acquisitions through physical and ideological dispossession of Indigenous inhabitants and cooptation of nativeness by settlers" (p. 314). Calderón's use of grammars reveals the ways narratives, discourses, and curricula function to erase and replace Indigenous peoples. Some of the settler grammars Calderón outlines include grammars of empty lands (Indigenous homelands were empty, and thus, available for the taking); the immigrant nation (the US is nation full of immigrants, and Indigenous peoples are simply earlier immigrants who migrated to the US via the land-bridge); the new Natives (because Indigenous peoples have vanished, settlers can now inherit Indigeneity and become "new" Natives); and settler superiority (cultures and institutions of settlers are superior to Indigenous peoples, whose cultures, institutions, and racialized bodies are "primitive" and "inferior").

Calderón's conception of settler grammars reveals the colonial logics and investments within the social studies curriculum specifically; however, her analysis can be used to make visible narrative methods of erasure and replacement in media more broadly. The logic that the US is an "immigrant nation," deployed even by those actively protesting dehumanizing policies, such as Executive Order 13769 (the travel ban in 2017 that targeted people from Muslim-majority countries), for example, erases Indigenous presence and perspectives. Further, settler grammars draw attention to ways national identity and nation-state formations are ideological, rather than natural (Anderson, 2006; Calderón, 2014). Moodie and Patrick (2017) use Calderón's settler grammars framework to expose how the Australian Professional Standards for Teachers (APSTs) and accreditation guidelines of Initial Teacher Education (ITE) programs reproduce Indigenous peoples as cultural artifacts subordinate to the interests of Australia. Settler grammars offer conceptual tools to recognize and denaturalize colonial logics in national and international contexts, a prerequisite for challenging them.

\section{Modeling Anticolonial Literacy in Practice}

In this section, we put Native studies theories to work on some current media texts as a means of modeling anticolonial media literacy. By looking to contemporary examples in media, we show how "firsting, replacing, and lasting" and "settler grammars" make visible colonial logics that might otherwise be ignored or concealed. As Calderón urges, we "must attend to the context of coloniality that we find ourselves in-in this case, a settler colonial society" which requires we first make explicit the settler grammars and thereafter confront and re-work them (p. 332). First, we look at media in curriculum, second, we turn to a photographic collection, and third, we analyze a political ad. 


\section{Celebrating Conquest}

In 2012, the City of Eugene celebrated its 150th birthday. In support of the event, the city produced five short educational videos, entitled "Hunting for History," to be used by 3rd and 4th grade teachers (City of Eugene, 2012). One of the videos, "Skinner's Donation Land Claim," features the story of how Eugene Skinner and his wife Mary came to the city. The video describes (though does not name), the Oregon Donation Land Claims Act of 1850:

Back in 1850, the federal government was looking for people to settle in the Oregon Territory in the Pacific Northwest. Married couples could receive up to 640 acres for free if they promised to work the land for at least four years. (City of Eugene, 2012)

In this framing, Indigenous lands are empty, a settler grammar that justifies settlement. Moreover, highlighting the arrival of Eugene and Mary Skinner illustrates the logic of firsting, a way of erasing Indigenous histories and celebrating settler presence.

The narrative methods of erasure and replacement are also evident in the video when a surveyor describes responsibilities of land surveyors:

We are the ones that set up where Mr. Skinner's grant was supposed to be. Before he was given the property, the surveyors had to come in, determine the boundary, make sure he had his 160 acres, and then, they filed the deed for him, and he was granted the property. We are one of the stewards of all the land. It's up to us to make sure we preserve all the boundary markers so everybody knows where their property is any time that they wish to know. (City of Eugene, 2012)

Anticolonial media literacy encourages students to interrogate the notion that lands were empty property, freely available to be claimed and settled, or the narrative that settlers (Skinner, and later surveyors) are the stewards of the land, the new natives of the place. Students might ask: Where were the Indigenous peoples in the video? What was this "government program" and how did it impact Indigenous peoples? How did Indigenous homelands come to be Skinner's property? Without guiding students to ask these questions, Indigenous dispossession will go unchallenged, glorified and celebrated again each year.

At a broader level, the birthday commemoration illustrates the rhetorical method of "firsting" by establishing and rehearsing settlement as the city's origin. So too does the name of the city, named after Eugene Skinner, the first settler to build a cabin near the base of a butte, which also now bears his name, "Skinner's Butte." Native studies theories equip students with tools to interrogate media-in this case, videos, newspaper articles, or radio advertisements about the event-that celebrates conquest, recognizing this city was "founded" atop homelands that were already lived in and loved, and that had their own names. Anticolonial media literacy also invites students to question what interests are tied up in specific types of media (Sullivan \& Tuana, 2007); in this case, citysponsored and city-produced media designed to legitimize its own presence, origin story, and innocence. 


\section{Jimmy Nelson and the Vanishing Race}

In his widely acclaimed TED Talk, "Gorgeous Portraits of the World's Vanishing People," which has been viewed by over 1.5 million people, Jimmy Nelson provides an array of stunning photographs of Indigenous peoples (Nelson, 2013). As the title of his TED Talk suggests, Indigenous subjects of his project are positioned as the remaining members of what he refers to as "fragile disappearing cultures." The talk, as well as his coffee table book entitled Before They Pass Away, each explicitly illustrates O'Brien's logic of "lasting." Despite the fact that the communities he photographs are actually teeming with Indigenous peoples, Nelson's TED Talk reproduces the narrative of Indigenous peoples as a vanishing race. Nelson didn't invent this narrative. His photos follow in the wake of photographers like Edward Curtis, whose vast collection, The North American Indian (1907-1930), was rooted in and reproduced this lasting logic. It is important that students can detect and interrupt this long-standing colonial trope.

Nelson's photographs are visually stunning. Each is rich with human emotion, landscapes, and bold colors. Anticolonial media literacy equips students to see beyond the stunning visuals and situates Nelson's work within a colonial legacy of positioning Indigenous peoples as vanishing and primitive. Lasting is a pervasive narrative in media, a narrative often compounded by colonial discourses of culture and authenticity (Raibmon, 2005). For example, though media representations may not explicitly suggest Native people have vanished, media might inadvertently reproduce the idea that "real" or "authentic" Indigenous peoples are disappearing. National Geographic, for example, admits its complicity in othering and exotifying Native life, conceding that its pattern of Indigenous representations erased Indigenous peoples in the countries in North America by positioning them as elsewhere, in Africa or Australia, for example (Goldberg, 2018). Anticolonial media literacy provides tools to analyze the longstanding pattern of positioning Indigenous peoples as an exotic and vanishing race, or as living elsewhere. That Nelson's TED Talk and published book were so widely circulated (over 1,597,769 views) illustrates not only the desire, audience, and market for this discourse of disappearance, but also the need for anticolonial media literacy skills to disrupt its momentum.

\section{Constructing Borders on Indigenous Homelands}

One of President Donald Trump's signature campaign promises of 2016 was to build a border wall between US and Mexico to prevent international crossing. Trump cites this wall in his current campaign media, often with racist and inflammatory rhetoric toward Chicanx and Latinx peoples, and specifically in his political ads on Facebook. In one post, paid for by the Trump Make America Great Again Committee, an image of Trump with his fist up is shown in front of a backdrop of construction materials and a waving flag (Trump Make America Great Again Committee, 2019). The post is accompanied by the text, "Add your name to support border security. Do you want to finish the Wall? Show the democrats you support President Trump's America first agenda!" When Trump posted the ad to Facebook, he also included a comment: 
The crisis at the Southern Border is even worse than most understand. I have taken MULTIPLE trips to the border to show the true invasion happening but the Democrats and the Fake News Media just won't listen. THE TIME IS NOW. WE NEED TO SECURE OUR BORDER!

Anticolonial media literacy can support students in critically reading this political ad specifically, and the border "crisis" more broadly.

Framing the border controversy as an issue between the US and Mexico, for example, erases the presence of Indigenous nations that reside in lands the border wall will traverse. Such framing is rooted in the grammar of settler superiority, foregrounding the primacy and interests of nation-states, while erasing concerns of Indigenous nations that have a legitimate stake in this international controversy. Students may not realize that the Tohono O'odham Nation resides within contested territory. Anticolonial media literacy encourages students to remember that all of the US was once Indigenous homelands and, in many places, Indigenous claims to those lands persist. The Tohono O'odham Nation has been deeply impacted by policies, practices, and discourses of the border. In February of 2020, construction crews began targeted blasting in Arizona's Organ Pipe Cactus National Park. The Tohono O'odham Nation, which stewards around 2.7 million acres in the Sonoran Desert, has opposed the border wall and condemned construction, which unearthed human remains and threatened larger sacred burial grounds. Anticolonial media literacy is premised on remembering that Indigenous nationhood and sovereignty persist, and as such, takes seriously concerns expressed by Indigenous nations that the wall will lead to ecological damage, disruption of water flow, threat of constant surveillance, and community/familial divides.

Anticolonial media literacy questions the political ground from which Trump declares that a wall is necessary to remedy a "true invasion" and protect "OUR BORDER." Such terms, again, legitimize the settler nation-state as the "new native," the authority and arbiter of the border dispute. Further, anticolonial media literacy encourages students to read between the lines, as well as remember the longer history of a place when viewing debates about the border in media. Back in the early 1850s, for example, the Gadsden Purchase allowed the US to purchase land in the southern area of New Mexico and Arizona and split up the Tohono O'odham Nation without their consent. This split is made more material as the Trump administration asserts settler nativism and the right to build a physical wall directly on Tohono O'odham land. Beyond ignoring and erasing important histories, the administration asserts settler superiority by using federal waivers associated with the 2005 REAL ID Act to avoid having to adhere to policies aimed at protecting these sites, such as the Native American Graves Protection and Repatriation Act. Now Native burial, archeological, and other sacred sites are being blown up without consultation with Native nations.

Anticolonial media literacy can help students decode the ways construction of the wall undermines sovereignty, understand how it will destroy important sacred and cultural sites, and recognize that it adds a physical reminder of US hegemony. As Wolfe (2006) stated, "Settler colonialism destroys to replace" (p. 388). Where before the Tohono O'odham Nation worked with the US and used their resources to protect their people, power is being usurped from them and taken to divide them from their relatives to the south. 
There is much to gain from reading political acts and ads with anticolonial literacy and listening to concerns of Indigenous peoples who have stewarded land in that regions for thousands of years as opposed to the US, who claim to have owned it for less than 170 years, and on tenuous legal grounds. Indigenous concerns also offer an important reminder to those who decry the border but deploy discourse that we are "a nation of immigrants" in doing so.

These three examples, which complicated the celebration of a town's founding, illuminated the discourse of Indigenous disappearance within a widely acclaimed TED Talk, and interjected Indigenous concerns into the controversy at the border, illuminate the power of Native studies theories to foster anticolonial media literacy. Although these examples were specific, our argument is these concepts of firsting, replacing, and lasting and settler grammars, along with other Native studies theories, can support students in denaturalizing and deconstructing colonial discourses often reproduced in media. The erasure and misrepresentation of Indigenous life, and the ways media reproduce colonial logics, are pervasive and varied. The story of Elizabeth Warren and her tenuous claims to Cherokee identity, for example, have saturated the media. Anticolonial media literacy can support students in detecting the colonial logics within this controversy and deconstruct settler grammars and discourses that undermine Indigenous sovereignty. By reading the ways media often ignores Indigenous perspectives, and by intentionally seeking them out, for example, students would learn that colonial racial blood logics, the discourse of "Native American Ancestry," and the practice of using DNA tests to authorize one's identity claims actually undermine Indigenous conceptions of identity and Indigenous sovereignty (TallBear, 2013).

The range and pervasiveness of Native misrepresentation and erasure is still a telling facet of our cultural moment but, notably, Indigenous peoples often intervene in their own erasure. Indigenous interventions into movements such as Occupy Wall Street or the Malheur Occupation, both of which asserted the lands being occupied or defended were (and continue to be) Indigenous homelands, are just two such examples. Anticolonial media literacy makes visible these erasures, reading not only for the ways Native peoples are mis/represented, but for the erasure of Indigenous peoples in contemporary discourses and current events. Anticolonial media literacy also seeks out Indigenous interventions.

\section{Beyond Critique and Toward Critical Indigenous Literacies}

Anticolonial media literacy can support students in detecting colonial logics within media representations, but teachers must also learn to find (and help students produce) meaningful alternative media. Native media activism, for example, has become a key way that Native communities have engaged in resistance, resurgence, and sovereignty (Sonza, 2018).There are numerous resources available to assist teachers' understanding of critical media literacy regarding race and nationhood. For example, UCLA Library aggregates videos, articles, cartoons, and other forms (see https://guides.library.ucla.edu/educ466). In addition, organizations such as Center for Media Literacy (http://www.medialit.org/), UNESCO's Center for Media Literacy (https://iite.unesco.org/pics/publications/en/files/3214705.pdf) and Media Literacy 
Clearinghouse (https://frankwbaker.com/mlc/) are readily available and eager to help. Teachers often need guidance, however, in selecting Indigenous-related media.

To support teachers in selecting accurate and respectful media, we turn to Nambé Pueblo scholar Debbie Reese's conception of critical Indigenous literacies. Reese's (2018) advice for selecting literature offers useful guideposts for selecting media:

The key ideas are to choose books that are tribally specific (that name a specific tribal nation and accurately present that nation), written by Native writers, set in the present day, and relevant all year round, keeping Native peoples visible throughout the school year. (p. 390, emphasis added)

Critical Indigenous literacy underlines the importance of understanding Tribal specificity and seeking out Native perspectives. Reese advocates for educators to visit websites of Tribal Nations to see how they represent themselves online. Critical Indigenous literacy also counters the dominant practice of including Indigenous-related representations primarily during November for Thanksgiving or Native Heritage Month, and instead offers students Native-related media year-round. Moreover, when stories include Indigenous characters, critical Indigenous literacies demand we take seriously the questions "Whose story is this? Who benefits from this story? Whose voices are not being heard?" (p. 390).

To model how critical Indigenous literacy can support media selection, we offer here several alternative anticolonial media representations that counter, supplement, or intervene into the three media examples discussed previously in this paper. Instead of uncritically showing the "Skinner's Donation Land Claim" video as class content, for example, teachers could use the documentary 'Broken Treaties,' An Oregon Experience (Cain, 2017) in which Native peoples from Oregon, including Tribal members, leaders, and historians, discuss their histories of dispossession as well as contemporary politics and lifeways of their Tribal Nations. Similarly, although Jimmy Nelson's TED Talk might be useful in the curriculum as a means of exposing the colonial trope of the vanishing race, or examining photography's complicity in colonialism, there are many Native photographers whose work can foster students' literacy around Indigenous peoples and issues. Native artists such as Wendy Red Star (Apsáalooke), Zig Jackson (Mandan, Hidatsa, and Arikara), and Will Wilson (Diné) create art to displace problematic stereotypes and foreground Native presence. Finally, political ads are but one way to study the border wall controversy. Students would also benefit from listening to journalistic interviews and reviewing social media from Native activists and politicians such as Verlon Jose, the Tribal Vice Chairman of the Tohono O'odham Nation. Vice Chairman Jose was recently interviewed by NPR, in a piece called "Native American Leader: 'A Wall Is Not the Answer'" (Greene \& Westernman, 2019) where he highlights impacts of the wall on his community.

These are specific examples to redress the harmful media previously discussed. However, there are additional organizations that offer resources on Indigenous-specific media content. Vision Maker Media (see https://www.visionmakermedia.org/), for example, is a non-profit that trains, supports, and showcases Native stories told through a variety of media including film, public television, and radio. Other organizations like PBS offer media literacy plans with Native-related content (see https://www.pbs.org /newshour/extra/daily-videos/lesson-plan-covington-catholic-incident-through-a-media- 
literacy-lens/. Seeking out these sources first requires teachers understand the ways media reproduces colonialism, a requisite for then seeking out counternarratives and complementary media representations.

As our paper makes clear, teachers can utilize Indigenous studies theories to foster anticolonial media literacy. We shared just two examples, "firsting, replacing, and lasting" and "settler grammars;" however theories like this abound. As an example, Unangax̂ scholar Eve Tuck's (2009) conception of "damage" and "desire" offers a means through which students can critically examine the ways Native people are included (and often pathologized) in media. Similarly, in a related piece, Tuck and Yang (2014) draw from Kahnawake Mohawk scholar Audra Simpson's (2007) concept of refusal to theorize how refusal can be both a generative practice and analytic. After critiquing Diane Sawyer's television special, "Hidden America: Children of the Plains," for its damagebased representation of the Pine Ridge Reservation rooted in "poverty porn" (p. 817), they highlight a generative contrast. The short film, "More Than That," produced by students from Toddy County High School on the Rosebud Sioux Reservation, refused and countered Sawyer's one-dimensional and pathologizing portrayal. The film began with a student commenting: "I know what you probably think of us/l saw the special too. Maybe you saw a picture or read an article. But we're here because we want you to know/we're more than that....We have so much more than poverty" (as cited in Tuck \& Yang, 2014, p. 817). Students then offered the visions and values of their community: "pride, humor, intelligence, determination, creativity, humility, appreciation, optimism, respect, and hope, hope, futures, futures, futures" (p. 817). This brief example illustrates how Native studies theories like desire, damage, and refusal support anticolonial media literacy, fostering students' abilities to critically interrogate, and even create, media. To reiterate, these theories are numerous. For example, Plains Cree scholar Emma La Roque's (2010) conception of the "civ/sav dichotomy," a way of positioning Indigenous life as primitive, savage, and inferior, and Western life as modern, civilized, and superior, offers a useful lens to detect the ways media representations may reproduce this colonial dichotomy. Similarly, Sabzalian's (2019b) anticolonial orientations for Indigenous studies curriculum-place, presence, perspectives, political nationhood, power, and partnerships - can guide educators in their selection of media representations. Native studies provides a generative set of theories, tools, and commitments to foster anticolonial media literacy.

\section{Conclusion}

A key recommendation in the report Reclaiming Native Truth (First Nations Development Institute \& Echo Hawk Consulting, 2018) involves the need for "narrative change" to "eradicate harmful and toxic narratives, stereotypes, structural and institutional racism, dehumanization, and the invisibility of Native Americans," and instead, "increase access to opportunities and rights and to ensure that Native Americans live in a society where they are celebrated as a vital part of the fabric of the United States as both leaders and key contributors" (p. 3). Critical Indigenous media literacy is an important way educators can enact this narrative change in their classrooms. However, until narrative change happens, there remains an urgent need for teachers and students to critically interrogate existing media representations, to engage in anticolonial media literacy. 
Because misrepresentation is so pervasive, teachers must not only offer students more humanizing media representations but must also teach students to detect and disrupt the constant flux of colonizing and dehumanizing representations of Indigenous peoples they see in media. Our hope is that anticolonial media literacy, coupled with critical Indigenous literacy, can foster the next generation of media producers who can, themselves, become narrative change agents.

\section{References}

Anderson, B. (1983/2006). Imagined communities: Reflections on the origin and spread of nationalism. New York, NY: Verso.

Attiah, K. (2020, June 13). Monuments of white supremacy obscure the history of colonial crimes. That's why they must come down. The Washington Post. https://www.washingtonpost.com/opinions/2020/06/13/monuments-whitesupremacy-obscure-history-colonial-crimes-thats-why-they-must-come-down/

Barthes, R. (1972). Mythologies. Hill \& Wang.

Brayboy, B. M. J. (2005). Toward a tribal critical race theory in education. The Urban Review, 37(5), 425-446.

Buckingham, D. (2013). Media education: Literacy, learning and contemporary culture. John Wiley \& Sons.

Cain, E. (2017). Broken treaties, an Oregon experience [Film]. PBS.

Calderón, D. (2014). Uncovering settler grammars in curriculum. Educational Studies, 50(4), 313-338.

City of Eugene. (2012). Hunting for history. [Video Files]. https://www.eugeneor.gov/2284/Hunting-for-History

Cook-Lynn, E. (1997). Who stole Native American studies? Wicazo Sa Review, 12(1), 9-28.

Cordes, A., \& Merskin, D. (2019). \#DontTrendOnMe: Addressing appropriation of Native American-ness in millennial social media. In Campbell, C. (Ed.). Media, myth and millennials: Critical perspectives on race and culture (pp. 277-299).: Lexington.

Curtis, E. S. (1907-1930). The North American Indian [Online]. Northwestern University Digital Library Collections. http://curtis.library.northwestern.edu/curtis/toc.cgi

First Nations Development Institute, \& Echo Hawk Consulting. (2018). Reclaiming Native truth: A project to dispel America's myths and misconceptions. Longmont, CO: First Nations Development Institute.

Fryberg, S., Markus, H., Oyserman, D., \& Stone, J. (2008). Of warrior chiefs and Indian princesses: The psychological consequences of American Indian mascots. Basic and Applied Social Psychology, 30(3), 208-218.

Fryberg, S. A., Covarrubias, R., Burack, J. A. (2016). The ongoing psychological colonization of North American indigenous people: Using social psychological 
theories to promote social justice. In Hammack, P. L. (Ed.), The Oxford handbook of social psychology and social justice. Oxford Press. doi:10.1093/oxfordhb/9780199938735.013.35

Goldberg, S. (2018, March 12). For decades our coverage was racist. To rise above our past, we must acknowledge it. National Geographic. https://www.national geographic.com/magazine/2018/04/from-the-editor-race-racism-history/

Gorski, P. C., \& Swalwell, K. (2015). Equity literacy for all. Educational Leadership, 72(6), 34-40.

Greene, D., \& Westerman, A. (2019). Native American leader: 'A wall Is not the answer.' NPR. https://www.npr.org/2019/01/23/685812553/native-american-leader-aborder-wall-is-not-the-answer

Hall, L. (2005). "Hawaiian at heart" and other fictions. The Contemporary Pacific, 17(2), 404-413.

Hall, S. (1997). Representation: Cultural representations and signifying practices. Sage.

Hawkman, A. M., \& Shear, S. B. (2017). "They're gonna sing the songs anyway": Thinking and teaching with theory and Disney music in elementary social studies. In S. Waters \& W. B. Russell III (Eds.). Cinematic social studies: A resource for teaching and learning social studies with film (pp. 55-78). Information Age.

Hawkman, A.M., \& Van Horn, S.E. (2019). What does it mean to be patriotic? Policing patriotism in sports and social studies education. The Social Studies, 110(3), 105-121.

Jenkins, H., \& Ito, M., \& boyd, d. (2016). Participatory culture in a networked era: A conversation on youth, learning, commerce, and politics. Malden, MA: Polity Press.

Hall, L. K. (2005). "Hawaiian at heart" and other fictions. The Contemporary Pacific, 17(2), 404-413.

King, L. (2017). The media and black masculinity: Looking at the media through race[d] lenses. Critical Education, 8(2), 31-40. http://ojs.library.ubc.ca/index.php/criticaled/article/view/186224

Kellner, D., \& Share, J. (2005). Toward critical media literacy: Core concepts, debates, organizations, and policy. Discourse: Studies in the cultural politics of education, 26(3), 369-386.

la paperson. (2017). A third university is possible. University of Minnesota Press.

LaRocque, E. (2010). When the other is me: Native resistance discourse, 1850-1990. University of Manitoba Press.

Lewis, R. (2006). Alanis Obomsawin: The vision of a Native filmmaker. University of Nebraska Press.

Lomawaima, K. T., \& McCarty, T. L. (2006). "To remain an Indian": Lessons in democracy from a century of Native American education. Teachers College Press. 
Lozenski, B., \& Chinang, G. (2019). Commodifying people, commodifying narratives: Toward a critical race media literacy. The International Journal of Critical Media Literacy, 1(1), 79-92.

Lyons, S. R. (2000). Rhetorical sovereignty: What do American Indians want from writing? College Composition and Communication, 51(3), 447-468.

Matias, C., \& Liou, D. (2015). Tending to the heart of communities of color. Urban Education, 50(5), 601-625.

McCue, D. (2014). What it takes for aboriginal people to make the news. $C B C$. https://www.cbc.ca/news/indigenous/what-it-takes-for-aboriginal-people-to-makethe-news-1.2514466

Moodie, N., \& Patrick, R. (2017). Settler grammars and the Australian professional standard for teaching. Asia-Pacific Journal of Teacher Education, 45(5), 439-454.

Moreton-Robinson, A. (2015). The white possessive: Property, power, and indigenous sovereignty. University of Minnesota Press.

Morrell, E. (2012). 21st-century literacies, critical media pedagogies, and language arts. The Reading Teacher, 66(4), 300-302.

Nelson, J. (2013). Before they pass away: Jimmy Nelson at TEDxAmsterdam [Video file]. https://www.youtube.com/watch?v=mPPxBpTP5hE

O'Brien, J. M. (2010). Firsting and lasting: Writing Indians out of existence in New England. Minnesota Press.

Patel, L. (2016). Decolonizing educational research: From ownership to answerability. Routledge.

Raibmon, P. (2005). Authentic Indians: Episodes of encounter from the late-nineteenthcentury Northwest coast. Duke University Press.

Raheja, M. H. (2010). Reservation reelism: Redfacing, visual sovereignty, and representations of Native Americans in film. University of Nebraska Press.

Reese, D. (2018). Critical Indigenous literacies: Selecting and using children's books about Indigenous peoples. Language Arts, 95(6), 389-393.

Robertson, D. W. (2015). Invisibility in the color-blind era: Examining legitimized racism against Indigenous peoples. American Indian Quarterly, 39(2), 113-153.

Rosiek, J., \& Kinslow, K. (2016). Resegregation as curriculum: The meaning of the new racial segregation in U.S. public schools. New York, NY: Routledge.

Rowe, A. C., \& Tuck, E. (2017). Settler colonialism and cultural studies: Ongoing settlement, cultural production, and resistance. Cultural Studies $\leftrightarrow$ Critical Methodologies, 17(1), 3-13.

Sabzalian, L. (2019a). Indigenous children's survivance in public schools. (Indigenous and Decolonizing Studies in Education). Routledge Education. 
Sabzalian, L. (2019b). The tension between Indigenous sovereignty and multicultural citizenship education: Toward an anticolonial approach to civic education. Theory \& Research in Social Education, 47(3), 311-346.

Shear, S.B. (2018). Teaching and learning using Indigenous-made films. Social Studies Journal, 38(2), 20-29.

Simpson, A. (2007). On ethnographic refusal: Indigeneity, "voice," and colonial citizenship. Junctures, 9, 67-80.

Smith, L. T. (2012). Decolonizing methodologies: Research and indigenous peoples (2nd ed.). Zed Books.

Sonza, L. (2018). Decolonizing vision: Native Americans, film and video activism. Video Journal of Education and Pedagogy, 3(12), 1-17.

Strong, P.T. (2004). The mascot slot: Cultural citizenship, political correctness, and pseudo-Indian sports symbols. Journal of Sport and Social Issues, 28(1), 79-87.

Sullivan, S., \& Tuana, N. (Eds.). (2007). Race and epistemologies of ignorance. Suny Press.

TallBear, K. (2013). Genomic articulations of indigeneity. Social Studies of Science, 43(3), 509-533.

Trump Make America Great Again Committee. (2019). The crisis at the Southern Borden [Advertisement]. https://www.facebook.com/ads/library/?active status=all\&ad_type=political_and_issue_ads\&country=US\&impression_search_ field=has_impressions_lifetime\&page_ids[0]=153080620724\&q=invasion

Tuck, E. (2009). Suspending damage: A letter to communities. Harvard Educational Review, 79(3), 409-428.

Tuck, E., \& Yang, K. W. (2012). Decolonization is not a metaphor. Decolonization: Indigeneity, Education and Society, 1, 1-40.

Tuck, E., \& Yang, K. W. (2014). Unbecoming claims: Pedagogies of refusal in qualitative research. Qualitative Inquiry, 20(6), 811-818.

White, F. (2017). Fashion and intolerance: Misappropriation of the war bonnet and mainstream anger. Journal of Popular Culture, 50(6), 1421-1436.

Wolfe, P. (2006). Settler-colonialism and the elimination of the Native. Journal of Genocide Research, 8(4), 387-409.

Yosso, T. J. (2002) Critical race media literacy: Challenging deficit discourse about Chicanas/os. Journal of Popular Film and Television, 30(1), 52-62. 
Author Contact

Ashley Cordes (Coquille), Ashley.Cordes@utah.edu

Department of Communication, 255 Central Campus Dr, Salt Lake City, UT 84112

Leilani Sabzalian (Alutiiq), leilanis@uoregon.edu

Department of Education Studies, 5277 University of Oregon, Eugene, OR, 97403-5277 